\title{
Polysèmes
}

Revue d'études intertextuelles et intermédiales

\section{To the Revolution and back: Wordsworth's painful crossings}

\section{Aurélie Thiria-Meulemans}

\section{(2) OpenEdition}

\section{Journals}

Édition électronique

URL : http://journals.openedition.org/polysemes/1499

DOI : 10.4000/polysemes. 1499

ISSN : 2496-4212

Éditeur

SAIT

Référence électronique

Aurélie Thiria-Meulemans, "To the Revolution and back: Wordsworth's painful crossings », Polysèmes [En ligne], 16 | 2016, mis en ligne le 15 novembre 2016, consulté le 21 avril 2019. URL : http:// journals.openedition.org/polysemes/1499; DOI : 10.4000/polysemes.1499

Ce document a été généré automatiquement le 21 avril 2019

Polysèmes 


\title{
To the Revolution and back: Wordsworth's painful crossings
}

\author{
Aurélie Thiria-Meulemans
}

1 Wordsworth's poetry, and particularly The Prelude, is full of crossings. Rivers, vales, and mountain chains are often crossed by Grasmere's walking poet. ${ }^{1}$ The most famous, if least glorious, of these episodes, is undoubtedly the passing of the Alps in book VI of The Prelude, when the poetic persona Wordsworth claims as his own, and his friend Robert Jones, realise they have indeed crossed the Alps, to use one of Wordsworth's favourite adverbs, "unawares". Not much is said in Wordsworth's thirteen-book epic about himself and his crossings of the English Channel, and yet they do bear a significant weight in the poet's lines and psyche. Not only do these crossings symbolically signal the poet's disobedience to his tutors and his stepping into adult life under the auspices of rebellion, at a time when rebellion on a broader scale was setting monarchies ablaze, they also metaphorically embody the poet's embracing of new political ideas: going to France when Wordsworth did, is crossing over to the revolutionary side.

2 Here, of course, is the limit of the metaphor: what space allows, time forbids. Although Wordsworth eventually went back to England and, later, back to conservative views, one can never go back in time, as the poet quickly realises when he returns to a completely changed England in 1792. Wordsworth left in France a part of his life he would never retrieve, or manage to erase entirely, try all he would. Stepping out of his unbearable suffering is going to imply a symbolic identification with Milton, "joint survivor" of a "failed revolution", and a rejection (and projection) of all his guilt onto French revolutionist Maximilien Robespierre, at the news of whose death the poet of The Prelude rejoices in the rise of a new era that looks suspiciously like innocence regained. 


\section{Experimenting with boundaries: Wordsworth's provocative crossings}

Book IX of The Prelude, "Residence in France", opens on a river metaphor. In these opening lines, however, it is the river that crosses:

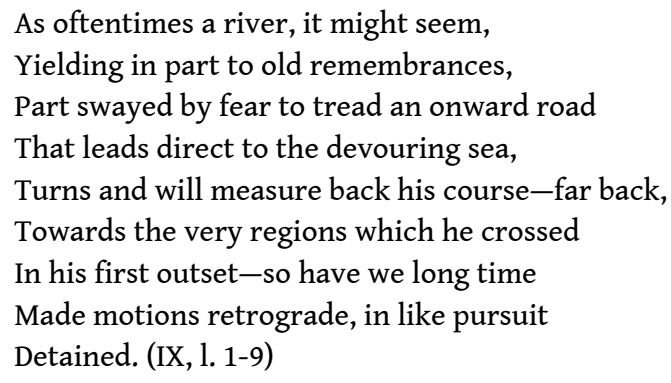

The river metaphor is recurrent in The Prelude as the stream of water, incapable of following the straight course of, say, a road, is a ready image of the mind of the poet and of the poem supposed to account for the maturation of this mind, retracing its "progress intricate". Here, Wordsworth consistently not only depicts his attitude to his past as literally fluctuating, but it is also himself he paints under the features of he who goes back to "the very regions which he crossed / In his first outset", and who does so by crossing the Channel: indeed, in 1791 Wordsworth decides to go back to France, giving as an excuse for this trip, "a personal wish / To speak the language more familiarly" (IX, 1. 36-37). "Wordsworth crossed from Brighton to Dieppe on the night of 26 November 1791" (Johnston 209). Yet this journey to revolutionary France is already Wordsworth's second one.

Wordsworth's first crossing of the Channel to France, two years earlier (on July $10^{\text {th }}, 1790$, from Dover to Calais) was not the usual well-planned, well-deserved holiday one might imagine. Wordsworth had to take his Cambridge examinations a few months later, and all of his friends warned him against this ill-advised trip. Going anyway was the first significant act of rebellion, in a chain of several that would ruin the hopes (and funds) his uncles $^{2}$ had placed in him and his career.

To journey to Europe instead at this crucial time not only threw him out of the system of preferment politics for which he was well groomed by family and personal interests, it also drew him into systems of thought, and among people, opposed not only to that comfortable system of benefices and emoluments, but to the entire ideology of hierarchy on which it was based. (Johnston 139)

In other words, the 1790 walking tour was a crossing whose degree of transgression almost equalled that of the Ullswater episode in book I, when the poet steals a small boat one night to enjoy a rowing excursion on the star-shimmering lake. On that occasion, the appearance of a cliff that cuts off the starlight forces him to go back, panting and ashamed. Choosing to cross over to the continent at a moment in his studies and in his life when so much was at stake was an unambiguous act of provocation towards his elders and their way of life. And apparently, even the cliffs of Dover were not enough to make him feel ashamed and go back this time.

Besides, the rebellious dimension of this trip also characterizes the manner of the tour, and not just its timing. Wordsworth and his Cambridge friend Robert Jones set off on and completed a kind of anti-Grand Tour, walking rather than using a chaise, and choosing Switzerland rather than Italy. In his Descriptive Sketches, Wordsworth insists on the 
difference between what he was doing and what Walpole and Gray had done fifty years earlier, when they were themselves Cambridge undergraduates, he underlines the "great difference between two companions lolling in a post chaise, and two travellers plodding slowly along the road, side by side, each with his little knapsack of necessaries upon his shoulders" (Johnston 141). Thus symbolically challenging their elders' way of travelling, Wordsworth and Jones seem to have been sights to rejoice at as they carried their coats on their heads, which certainly helped them keep the incredible pace of that trip in which they "covered 2000 miles" and "averaged nearly thirty miles a day, mostly on foot" (Johnston 143) in no more than three months.

6 Eager to escape his uncles' plan for him to accept a curacy, and arguing he might become a language tutor for young noblemen on their Grand Tour, Wordsworth crossed the channel once more in 1792, "more like a man / Flying from something he dreads, than one / Who sought the thing he loved", to quote from "Tintern Abbey". Joining Paris through Rouen, Wordsworth arrived a few weeks later at his planned destination of Orléans, where he made two fateful acquaintances: that of Annette Vallon and that of Michel de Beaupuy. Because of or thanks to them, other lines were crossed. A young Englishman expected to become a clergyman in the Church of England by uncles who had paid for his education and still paid for his maintenance, fell in love with and soon fathered a child to a Catholic French woman. And Beaupuy, in charge of the Thirtysecond Bassigny regiment in Blois was more than partly responsible for Wordsworth's conversion to the new good cause of la Révolution.

Meanwhile, the latter was speeding up on its own fateful one-way path. On August $10^{\text {th }}$, the Tuileries were invaded, the monarchy suspended, the King arrested, and the National Assembly dissolved into a National Convention. On the $26^{\text {th }}$, as an army of émigré princes crossed the eastern border at Longwy, the fear-incensed mob of Paris started to slaughter traitorous-looking prisoners for three days. At that very moment, upon his being refused more funds by uncles who must have heard of their nephew's ever more provocative transgressions, a desperate Wordsworth goes back to Paris in a hurry, to return to England hoping he'll be more lucky if he pleads his cause in person, and obtain fresh funds for the maintenance of his new family. Biographers wonder at Wordsworth's staying six weeks in Paris at a moment when there was no time to be lost. Was he having difficulties procuring a passport or was it sheer fascination for times of change when it seemed that one man could rise and save or ruin the hopes of an entire people? Indeed,

An insignificant stranger and obscure,

Mean as I was, and little graced with powers

of eloquence even in my native speech,

And all unfit for tumult and intrigue,

Yet would I willingly have taken up

A service at this time for cause so great,

However dangerous. (X, 1. 130-136)

Involvement in the revolution, however, is one line Wordsworth apparently did not cross, according to most biographers, although David Bromwich reads in the persistent guilt that transpires in The Prelude's revolutionary books a hint at the idea that Wordsworth might have been more involved than he cared to admit, and that one of his actions probably resulted in somebody's execution (17). Fascinated or involved, Wordsworth had to leave the capital of the young French Republic. "Reluctantly, to England I returned / Compelled by nothing less than absolute want / of funds for my support" (X, 1. 189-190). 


\section{No way back: the impossible crossings}

On December $15^{\text {th }}$, one Anne-Caroline Wordwodsth [sic] was christened in Orléans cathedral, while her father is said by Dorothy to be back in London in a letter dated December $22^{\text {nd }}$. But the country Wordsworth had just crossed back to was very different from the one he had left. The polarization of public opinion around the issue of the Revolution is greater than ever, and worse, France declares war on England on February 1 st, 1793. Only a few radicals keep supporting the Revolution. Its increasingly violent course (King Louis was executed on January $21^{\text {st }}$ ) had turned English public opinion against it, and with the war starting, the population naturally chose to support their troops. At that time and place, Wordsworth felt trapped in a triple betrayal: that of Annette by himself (as he is unable to procure funds, therefore go back, therefore marry, which means she is also prevented from raising her child), that of himself the liberal thinker by a country known worldwide as the protector of freedom and which is now openly waging war on freedom, and that of England by himself, who, in times of war, supports France (the country of both his paramour and his political ideals) against his own country. A famous excerpt from The Prelude encapsulates this dilemma:

... I felt

The ravage of this most unnatural strife

In my own heart; there lay it like a weight,

An enmity with all the tenderest springs

of my enjoyments. I, who with the breeze

Had played, a green leaf on the blessed tree

of my beloved country-nor had wished

For happier fortune than to wither there-

Now from my pleasant station was cut off,

And tossed about in whirlwinds. I rejoiced,

Yes, afterwards, truth painful to record,

Exulted in the triumph of my soul

When Englishmen by thousands were o'erthrown,

Left without glory on the field, or driven,

Brave hearts, to shameful flight. It was a grief-

Grief call it not, 'twas any thing but that-

A conflict of sensations without name,

Of which he only who may love the sight

of a village steeple as I do can judge,

When in the congregation, bending all

To their great Father, prayers were offered up

Or praises for our country's victories,

And, 'mid the simple worshippers perchance

I only, like an uninvited guest

Whom no one owned, sate silent-shall I add,

Fed on the day of revenge yet to come! (X, 1. 249-274)

Going back to these moments is itself painful. The poet can barely find words to express his mental discomfort at being back in a homeland where he feels he all but belongs ("whom no one owned"). His situation evokes that of the poor shepherd in book VIII of The Prelude who jumped on a rock to save a sheep but finds himself trapped in the middle of the stream:

Thrice did he turn his face

To either brink, nor could he summon up

The courage that was needful to leap back 
Cross the tempestuous torrent: so he stood,

A prisoner on the island, not without

More than one thought of death and his last hour. (VIII, 1. 284-289) was to claim his difference, and declare himself an enemy of that establishment that had chosen to exclude him. On January 30th (one day after the publication of An Evening Walk and Descriptive Sketches), Richard Watson, bishop of Llandaff, published an appendix to an old sermon in which he openly changed sides and recanted his former support for the French Revolution. Watson was the most liberal prelate of his time, and furthermore, a Windermere estate-owner, in other words an "all around Lake District success story", as Kenneth Johnston puts it, who must have been produced in front of Wordsworth's eyes many times as a role model. This ultimate betrayal on the eve of war, certainly accounts for the anger one senses in Wordsworth's response to that text, his famous "Letter to the Bishop of Llandaff" "by A Republican", which was, however, never published. Denouncing the hypocrisy of the prelate and his well-timed coat-turning, Wordsworth uses a local expression both men were sure to know: "In some parts of England it is quaintly said, when a drunken man is seen reeling towards his home, that he has business on both sides of the road" (Johnston 246). Having himself business on both sides of the Channel, Wordsworth simply could not bear the betrayal of the last member of the establishment of whom he still approved.

11 Wordsworth's ideological evolution in the 1790s is widely documented, from his acquaintance with Godwin, which led to a growing caution regarding the idea of a revolution, and an interest for moral concerns over political ones, to the turning towards a poetic revolution, though with obvious political undertones, with the publication of Lyrical Ballads, and its famous preface, which, as Johnston brilliantly summarizes, has him move on from insisting on "the immorality of nobles to the nobility of the poor". ${ }^{3} \mathrm{Had}$ Wordsworth then managed to reach a safe harbour, publically recognized as he was as the man who revolutionized poetry, but only privately known to have been a radical, a defender of the French regicide? Some lines in The Prelude, in which he goes back to his experience of the French Revolution, suggest otherwise.

o friend,

It was a lamentable time for man,

Whether a hope had never been his or not;

A woeful time for them whose hopes did still

Outlast the shock; most woeful for those few-

They had the deepest feeling of the grief-

Who still were flattered, and had trust in man.

Meanwhile, the invaders fared as they deserved:

The herculean Commonwealth had put forth her arms, 
And throttled with an infant godhead's might

The snakes about her cradle-that was well,

And as it should be, yet no cure for those

Whose souls were sick with pain of what would be

Hereafter, brought in charge against mankind.

Most melancholy at that time, $O$ friend,

Were my day-thoughts, my dreams were miserable;

Through months, through years, long after the last beat

Of those atrocities (I speak bare truth,

As if to thee alone in private talk)

I scarcely had a night of quiet sleep,

Such ghastly visions had I of despair,

And tyranny, and implements of death,

And long orations which in dreams I pleaded

Before unjust tribunals, with a voice

Labouring, a brain confounded and a sense

of treachery and desertion in the place

The holiest that I knew of-my own soul. (1805, X, 1. 373-380)

More is kept quiet than is confessed in these enigmatic lines. Indeed, nowhere in The Prelude does Wordsworth mention his affair with Annette Vallon (covered up in the story of Vaudracour and Julia in the 1805 Prelude, which was published separately in 1820 and suppressed from the 1850 version). Johnston reads in them the confession of a third crossing to France in the fall of 1793, which he evidences rather convincingly. Although foreigners were not at risk in Paris the last time Wordsworth had been there (in December 1792), they had become fatefully suspects by September 1793. Johnston believes Wordsworth tried to reach Annette, but could not, as the Vendée rebellion was then raging in the West of France, making any crossing of these regions far too dangerous, and went back to England without seeing her. One would expect such lines of anguish to have been written in the heat of it. They indeed recall the feelings of the poet in his Paris room, recalling "those September massacres / Divided from me by a little month" in the autumn of 1792. Then his life was threatened, being in Paris was dangerous. Therefore, why such dread a posteriori? The tribunals that would trouble Wordsworth's dreams at the time seem wholly interior: it is not for his head he fears, but for his soul, he who abandoned a woman whom he had sworn to marry and a child, near where the fierce battles of the Vendée took place. The dreaded tribunal is not composed of "the bloodthirsty hounds" Dickens described in A Tale of Two Cities, but of his own readers.

One knows it is usual in The Prelude to find instances of the poet's cruel fantasies about his readers' reactions, and more painfully about the poet's own helplessness in front of these almighty judges. The episode of the Blind Beggar best exemplifies Wordsworth's complex and painful relationship to his readership:

lost

Amid the moving pageant, 'twas my chance

Abruptly to be smitten with the view

of a blind beggar, who, with upright face,

Stood propped against a wall, upon his chest

Wearing a written paper, to explain

The story of the man, and who he was.

My mind did at this spectacle turn round

As with the might of waters, and it seemed

To me that in this label was a type

Or emblem of the utmost that we know

Both of ourselves and of the universe, 
And on the shape of this unmoving man,

His fixéd face and sightless eyes, I looked,

As if admonished from another world. (VII, 1. 599-623) (which Wordsworth never could bring himself to publish while he was alive), are a metaphor called for by the sense of guilt that transpires in the lines. Some readers might be willing to convict Wordsworth for the exact opposite of what a revolutionary tribunal would have reproached him with: his revolutionary ideals. The crossing he fears is not that of the Styx; the threat of la Sainte Guillotine is over and gone. What Wordsworth laments is the impossibility for the poet to cross over the page, and reach out to his reader to gain his or her empathy. Knowing that his readers can and will judge him for his youthful errors, the poet fears he cannot defend himself in absentia. The page embodies the impossible crossing, the tragic and necessary indirection in the relation to the reader. Each on one side of the page, like Narcissus and his reflection, the two can never meet. Although in many lyrics, Wordsworth somehow turns the reader into a double of himself, here, in the tale of his own individual and therefore unique past, the poet stands alone and vulnerable, like a blind beggar in the busy streets of London. His mind "turns round" and it is the beggar, his double, who has to "prop himself against a wall".

\section{Pro/re-jecting blame: doubles as stepping stones back to innocence}

16 Another blind man haunts Wordsworth's verse, filling him, this time, not with dread, but with reassurance. John Milton, for Harold Bloom, is to Wordsworth the castrating fatherfigure whom the romantic poet had to misread in order to escape his grasp, and so as not to stifle in his influence (1976 passim). The two poets have indeed highly different styles, as Wordsworth's notes on his own copy of Paradise Lost, condemning artificial metaphors and too much ornament, clearly suggest (Hunt passim). Many critics, however, underline an important common point between the two poets: they both survived the failure of a revolution that had put their faith in. Both Abrams (passim) and Bloom (1971 passim) have shown how the romantics turned to the Puritans in order to understand and represent the failure of their own beliefs. Nicola Zoe Trott, picking up a line from The Borderers, calls Milton and Wordsworth "joint sufferers of failed revolutions" (115).

17 I have shown (Thiria-Meulemans 90-95) how Wordsworth uses Milton to reassure himself at a time in his life when his doubts regarding his poetic calling were made all the more painful by the failure of a revolution he had believed in. Milton becomes an ideal of the 
self that needs not fear harsh judgment from rash readers. It is particularly clear in the 1794 addition to "An Evening Walk" quoted by N.Z. Trott.

So virtue, fallen on times to gloom consigned,

Makes round her path the light she cannot find,

And by her own internal lamp fulfils,

And asks no other star what Virtue wills,

Acknowledging, though round her danger lurk,

And Fear, no night in which she cannot work;

In dangerous night so Milton worked alone,

Cheared by a secret lustre all his own,

That with the deepening darkness clearer shone. (Selincourt 35)

Wordsworth describes Milton as managing to survive a predicament that suspiciously resembles his own. No need to fear judgment from the other side of the page; his side, the author's side, is safe, since it is also Milton's, the poet-prophet whom no one would dare to accuse. The "long orations... before unjust tribunals" become fantasmatically eloquent and irreproachable, brought closer as they are, to Milton's prophetic verse.

Yet, at the same time, Wordsworth convenes that "danger lurk[s]", and Milton is more of a buoy than a safe shore. Crossing back to solid ground implies for Wordsworth the use of another double, a scapegoat whose use consists in being burdened with all the weight of his own guilt, so that his death might be cleansing. In The Prelude, Robespierre is named and shamed, almost alone among the great names of the Terreur, rejected as the embodiment of everything about Wordsworth he wanted to get rid of as he grew older. Unease vis-à-vis his former political faith transpires in the lines of The Prelude nowhere more clearly than in the lines concerning the death of l'Incorruptible.

I paused,

Unwilling to proceed, the scene appeared

So gay and cheerful-when a traveller

Chancing to pass, I carelessly inquired

If any news were stirring, he replied

In the familiar language of the day

That, Robespierre was dead. Nor was a doubt,

On further question, left within my mind

But that the tidings were substantial truth-

That he and his supporters all were fallen.

Great was my glee of spirit, great my joy

In vengeance, and eternal justice, thus

Made manifest. "Come now, ye golden times",

Said I, forth-breathing on those open sands

A hymn of triumph, "as the morning comes

Out of the bosom of the night come ye..."

[...]

Thus, interrupted by uneasy bursts

Of exultation, I pursued my way

Along that very shore which I had skimmed

In former times, when, spurring from the Vale

of Nightshade, and St. Mary's mouldering fane,

And the stone abbot, after circuit made

In wantonness of heart, a joyous crew

Of schoolboys, hastening to their distant home,

Along the margin of the moonlight sea,

We beat with thundering hoofs the level sand. (X, 1.529-566) 
19 accompanying the thought of "the glorious days" to come is a direct echo of and response to the "Bliss" felt at first by the poet when the country was celebrating the Fête de la Fédération on July $14^{\text {th }}, 1790$. "Bliss was it in that dawn to be alive, / But to be young was very heaven!" (X, 1.692-693). Let it be known to the readers that the young man who rejoiced at the time in the rise of a new era has later matured, and rejoiced, more appropriately, in the death of one of the most blood-thirsty leaders of the French Revolution. Moreover, this Robespierre-bashing seems to be serving an important psychological purpose, to quote Richard Gravil, "Robespierre appears as having incarnated Wordsworth's own revolutionary self, [...] which the poet of 1805 is relieved to lay to rest" (136). Gravil insists that the palpable feeling of relief felt through these lines pertains more to the writing of that moment than to its actual experience. For Wordsworth this corresponds to no less than "the dethroning of his Godwinian self" (Gravil 140). Still, the "bursts of exultation" remain "uneasy". Finally, the end of the passage, when the poet coincidentally recalls his horse rides as a child is indeed revealing: going back to the death of Robespierre in such a way enables him to regain the innocence of childhood. If the real Wordsworth cannot go back to his revolutionary days, go back to Annette, or go back to the golden days they knew together in Blois, his lines at least can achieve the impossible crossing back to youth and innocence, although his position on the beach somehow betrays once more the impossibility of a way back.

Written between 1795 and 1797, The Borderers, a tragedy and Wordsworth's only play, stages a naïve idealistic hero, Marmaduke, tricked into murdering a man by cynical Oswald who professes to be committed to cold reason only. While the play deals with Scottish rovers at the time of Henry III, it does revolve around the question of moral boundaries as well, as its title echoes-no matter the ideal in sight, murder is the ultimate crossing every man must refuse to attempt. Oswald, The Borderers' villain, who may or may not have been named after the leader of a British club of radicals in revolutionary Paris, Colonel John Oswald, ${ }^{4}$ is another Robespierre-like double. The poet loads him with all the weight of his personal guilt, to better free himself from that feeling. It is therefore revealing that Wordsworth should have chosen to express through Oswald's mouth his most grandiose definition of action as a crossing with no way back.

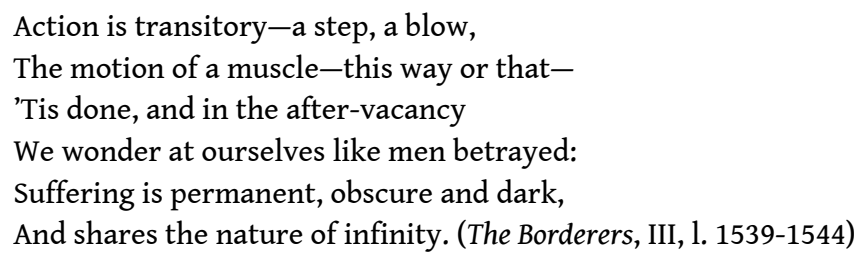

Thought, however, whose material is the after-vacancy left by action, is entrusted with the impossible task of figuring out a way back which consists not only in suffering, but, in Wordsworth's case, in the written record of that suffering, the action of writing verse, with its physical obligation of going back to the beginning of the line, the left margin of the page, mimicking the attempt of the lines' content. Eventually, one could interpret the constant rewriting of The Prelude throughout Wordsworth's life as so many attempts at figuring out a way back, or rather figuring out that as long as one keeps writing, the other shore is still in sight. 


\section{BIBLIOGRAPHIE}

Abrams, M.H. "English Romanticism: The Spirit of the Age". Romanticism and Consciousness.

Ed. Harold Bloom. New York: Norton, 1990.

Bloom, Harold. The Visionary Company: A Reading of English Romantic Poetry. Revised edition. Ithaca:

Cornell UP, 1971.

Bloom, Harold. "Wordsworth and the Scene of Instruction". Poetry and Repression. New Haven:

Yale UP, 1976.

Bromwich, David. Disowned by Memory: Wordsworth's Poetry of the 1790s. Chicago: U of Chicago P, 1998.

Chandler, James. Wordsworth's Second Nature. A Study of the Poetry and Politics. Chicago: U of Chicago $\mathrm{P}, 1984$.

Gaillet de Chezelles, Florence. Wordsworth et la marche. Parcours poétique et esthétique. Grenoble : Ellug, 2007.

Gill, Stephen. William Wordsworth. A Life. Oxford: Clarendon, 1989.

Gravil, Richard. “'Some other Being': Wordsworth in The Prelude”. Yearbook of English Studies 19 (1989): 127-143.

Hazlitt, William. "Lectures on the English Poets VII: On the Living Poets". The Selected Writings of William Hazlitt. Ed. Duncan Wu. Vol. 2. London: Pickering and Chatto, 1998.

Hunt, Bishop C. "Wordsworth's Marginalia on Paradise Lost". Bulletin of the New York Public Library 73 (1969): 167-183.

Johnston, Kenneth. The Hidden Wordsworth (1998). New York \& London: Norton, 2001.

Roe, Nicholas. Wordsworth and Coleridge. The Radical Years. Oxford: Clarendon, 1988.

Rogers, Rachel. Vectors of Revolution, the British Radical Community in Early Republican Paris, 1792-1794 . Thèse de Doctorat, Université Toulouse II, 2012.

Thiria-Meulemans, Aurélie. Wordsworth et ses miroirs. Résonances des mythes d'Écho et de Narcisse. Grenoble : Ellug, 2014.

Wordsworth, William. The Prelude: 1799, 1805, 1850. Ed. Jonathan Wordsworth, M.H. Abrams, \& Stephen Gill. New York: Norton, 1979.

Wordsworth, William. The Prelude: The Four Texts $(1798,1799,1805,1850)$. Ed. Jonathan Wordsworth. London: Penguin Classics, 1995.

Wordsworth, William. The Poetical Works of William Wordsworth. Ed. Ernest de Selincourt \& Helen Darbishire (1940). $2^{\text {nd }}$ ed. Vol. I, Oxford: Clarendon Press, 1952.

The Letters of William and Dorothy Wordsworth. Vol. I. The Early Years, 1787-1805. Ed. Ernest de Selincourt. $2^{\text {nd }}$ ed. Rev. Chester L. Shaver. Oxford: Clarendon Press, 1967. 


\section{NOTES}

1. See Florence Gaillet-de Chezelles, Wordsworth et la marche. Parcours poétique et esthétique, Grenoble: Ellug, 2007.

2. The Cookson uncles and Richard Robinson.

3. One thinks of Hazlitt and what he says of Wordsworth in his Lectures on the Living Poets (314-315): "All the common-place figures of poetry, tropes, allegories, personifications, with the whole heathen mythology, were instantly discarded; a classical allusion was considered as a piece of antiquated foppery; capital letters were no more allowed in print, than letters-patent of nobility were permitted in real life; kings and queens were dethroned from their rank and station in legitimate tragedy or epic poetry, as they were decapitated elsewhere; rhyme was looked upon as a relic of the feudal system, and regular metre was abolished along with regular government". 4. See Rachel Rogers, Vectors of Revolution, the British Radical Community in Early Republican Paris, 1792-1794.

\section{RÉSUMÉS}

Lorsque Wordsworth traverse la Manche en 1791 pour retourner séjourner en France, il accomplit d'un coup diverses transgressions: il désobéit à ses oncles, compromet son avenir professionnel, et rejoint le camp des idées nouvelles. Contraint de rentrer au pays dans l'espoir de trouver des subsides pour la famille illégitime qu'il vient de fonder dans un nouvel acte transgressif, Wordsworth s'aperçoit bien vite que tout retour n'est que chimère. L'Angleterre qu'il retrouve n'est pas celle qu'il a quittée, Annette est devenue impossible à rejoindre. Le passé et son innocence perdue ne sont pas plus accessibles que ne le sont ses futurs lecteurs qu'il craint de ne pouvoir convaincre dans des vers empreints d'une culpabilité déchirante. Le chemin du retour, vers une forme de paix intérieure et d'appartenance apaisée à la communauté nationale, est pavé pour Wordsworth de doubles, choisis ou reniés. Avec Milton, le poète s'invente un frère, compagnon d'infortune, survivant lui aussi d'une révolution manquée. Avec Robespierre, il trouve un bouc émissaire qu'il charge du poids de sa culpabilité, et dont la mort le libère.

The crossing of the Channel to revolutionary France was a symbolic transgression for Wordsworth, on various levels: he was disobeying his uncles, compromising his future, and joining the revolutionary side. Forced to go back to get funds for the illegitimate family he had founded in yet another act of transgression, Wordsworth realises that there is in fact no going back. His motherland has changed, his French family cannot be reached, and there is no more going back to the past and its innocence as there is a possibility of crossing over to the reader of The Prelude to win his or her sympathy in lines that transpire with guilt. Eventually, the poet uses historical figures as doubles to help him get back to a safe harbour of inner peace and acceptable Britishness. Wordsworth identifies with Milton as the joint survivor of a failed revolution, and rejects all his sense of guilt onto Robespierre whose death signals the return of innocence. 
INDEX

Mots-clés : Révolution française, traversée

Keywords : French Revolution, crossing

oeuvrecitee Borderers (The), Prelude (The)

\section{AUTEURS}

\section{AURÉLIE THIRIA-MEULEMANS}

Ancienne élève de l'ENS de Lyon et agrégée d'anglais, Aurélie Thiria-Meulemans est maître de conférences à l'Université de Picardie - Jules Verne. Outre plusieurs articles sur Wordsworth, elle a publié en 2014 Wordsworth et ses Miroirs, Résonances des mythes d'Écho et de Narcisse (Ellug). 